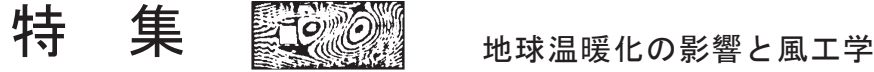

\section{最大潜在強度理論による将来の温暖化した環境における台風強度の定量化 Quantification of Tropical Cyclone Intensities in Warmed Future Environments Using a Maximum Potential Intensity Theory}

筒井純一 $*$

Junichi TSUTSUI

\section{1.はじめに}

表題の最大潜在強度 (Maximum Potential Intensity: MPI) は，台風等の熱帯低気圧（以下，単に台風と呼ぶ）の発 達限界を定量化する理論的枠組みである。発達限界とい うのは, 与えられた熱環境 (海面水温や上空の気温分布) の下で発達し得る最大の強度であり, 最大風速や最低中 心気圧で表される。MPI の理論は，地球温暖化の問題が 注目され始めた 1980-90 年代に, Emanuel ${ }^{1,2)}$ と Holland ${ }^{3)}$ によって，それぞれ異なる方式が提唱された。同様の考 え方は以前からあったようであるが，通常 MPI と呼ばれ るのは，両者の方式のいずれかである。本稿では Holland の方式を取り上げる。MPI に関する包括的な情報は文献 4)に詳しい。

地球温暖化に伴う台風の変化やその影響の評価は, 特 に最近では, 高解像度の気候モデルによるダウンスケー リングとその出力結果を用いる方法が主流である。その 中で，MPI は，地球温暖化によって台風が強大化する可 能性を理論的に説明する役割を果たしてきた。台風は, 海面水温が $26^{\circ} \mathrm{C}$ 以上の海域で発生し, 海面水温が高いほ ど強度が増すことが経験的に知られている。MPI の理論 によれば，現状気候における経験的な関係が温暖化した 環境にそのまま当てはまるわけではないものの, 温暖化 によって強度が幾分か増すことが示される（図 1）5）

MPI が地球温暖化研究で限定的な役割に留まっている のは，MPI からは強度以外の情報が得られないこと，お
よびその強度が発達に適した理想的な環境で評価される ものであって, 発達を阻害する様々な環境要因は考慮さ れないことによると思われる。しかしながら，このこと は，不確実性の避けられない地球温暖化予測情報を工学 的な問題に応用する場合は, 見通しの良い結果を得ると いう意味で有用な点でもある。

構造物の設計に使われる風荷重の基準が，その地域に おける過去の最強クラスの台風に基づく場合, 気候モデ ル計算に基づく評価では，局所的かつ非常に稀な事象を 扱うことから困難を伴う。最強クラスの台風は，理想的 な環境で発生・発達すると考えられるので, MPI で扱う

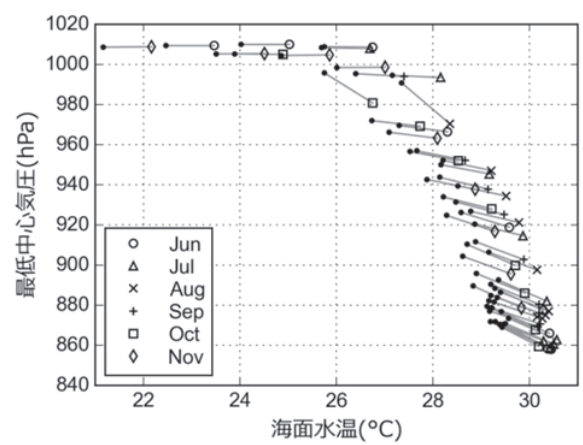

図 1 MPI（最低中心気圧）と海面水温の関係 文献 ${ }^{5}$ Fig. 7 に基づく。12.5-32.5N，122.5-145E の月別南北 2.5 度 間隔の東西平均場で，現状と温暖化した気候の MPI を計算した 結果。それぞれ黒点と月別のマーカで表し, 個別に線で結んでい る。温暖化した気候は, 海面水温が一律 $1^{\circ} \mathrm{C}$ 上昇する設定。

* 電力中央研究所 環境科学研究所 副研究参事

Deputy Associate Vice President, Environmental Science Research Laboratory, Central Research Institute of Electric Power Industry 
のに適している。最強クラスの台風が来襲する頻度につ いては, 元々自然の変動が大きく, 地球温暖化による変 化は現状では良くわかっていない。これは，一貫性のあ る観測記録の得られる期間が限られこと,および頻度を 左右する環境要因（エルニーニョなど）や，その要因の 地球温暖化による変化についての理解が不十分であるこ とによるの。

MPI の計算から台風強度を評価する場合, 入力条件と して与える熱環境の不確実性を考慮する必要がある。地 球温暖化に伴う将来の熱環境は, 大気・海洋結合大循環 モデル (Atmosphere-Ocean General Circulation Model: AOGCM）と呼ばれる複雑な気候モデルの出力情報から 得られる。AOGCM は世界中の研究機関で多数開発され ており, 互いに計算結果が異なる。結果の相違には, 気 温等の気候要素の空間分布だけでなく, 大気 $\mathrm{CO}_{2}$ 濃度な どの加熱効果（放射強制力）に対する全球規模の気温応 答の大きさ (気候感度) も関係する。さらに, AOGCM の入力情報となる $\mathrm{CO}_{2}$ 等の排出量や大気中濃度の変化に ついても, 多数のシナリオが考えられる。このような AOGCM やシナリオの不確実性は, 地球温暖化の予測や 影響評価で常に問題になることであり, ダウンスケーリ ングの場合にも当てはまる。MPI の計算コストはダウン スケーリングに比べて無視できるほど小さく, AOGCM のばらつきや多数のシナリオを扱う確率論的な評価では, MPI の手法が特に有用である。

このような MPI の利点を考慮して, 本稿では, MPIに よる評価法と, 台風シーズン最盛期の日本近海の熱環境 に対する評価結果を説明する。いずれも既往研究の成果 5,7)であるが, AOGCM の気候感度については最新の知見 を取り入れた評価結果も紹介する。

\section{2. 方法論 \\ 2. 1 MPI 理論}

台風は, 図 2 に示寸ように, 軸対象の暖気核 (同じ高 度の周囲と比べて気温が高い）構造をもつ。暖気核が形 成されるのは, 海面付近の湿った気塊が対流によって上 昇寸る過程で潜熱が放出されることによる。上空の気温 が高くなる（密度が低くなる）と, 地表面の気圧が低下 する (静力学平衡)。この時, 暖かい海洋から熱が供給さ れて海面付近の気温が一定に保たれると, 上昇する気塊 のエネルギーが増加して, より多くの潜熱が放出される ようになる。台風の発達では, このような対流による潜 熱放出と海洋からの熱供給の相乗効果が重要である。

Emanuel の理論では, 海洋からの熱供給と, 大気・海

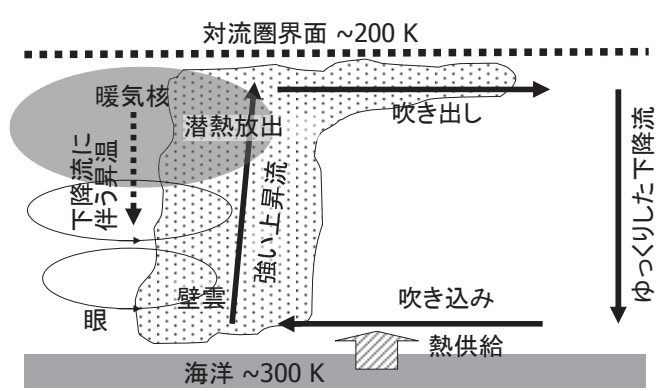

図2 台風の暖気核構造の仕組み

洋間の摩擦による運動エネルギーの散逸のバランスから, 定常状態の台風で維持される地表付近の最大風速が定式 化されている。その中では, 海洋から供給されるエネル ギーの利用効率が，海面付近と台風上空の気温差で表さ れ, カルノーサイクルの熱機関との類似性から, 台風が 一種の熱機関として捉えられている。一方, Holland の理 論では, 暖気核形成に関わる熱力学的な過程に, 台風の 眼の効果 (下降流に伴う昇温) も加えて, 中心気圧の下 限值が定式化されている。両者とも, 個々の台風強度の 予報には制約があるが 8 ,9), 熱環境が地球規模で変化する 地球温暖化の場合は，その正味の効果を定量化するのに 役立つ ${ }^{10-13)}$ 。二つの方式では, Holland の MPI の方が地球 規模の温度上昇に対する感度が大きいようであるの。ただ し，いずれの方式も環境の相対湿度などの調整パラメー タがあり, 細かい点も含めて異なる実装がある。

MPI は海面水温と上空の気温の両方に依存し, 海面水 温がより高く, 上空の環境気温がより低いほど, 最大風 速もしくは気圧深度（台風周辺の海面気圧から中心気圧 を引いた差）で表される MPI の值は大きくなる。地球温 暖化による気温上昇は, 水蒸気を含む大気の熱力学的な 性質により，熱帯の対流圈では上空に向かって拡大する。 このことは, 海面水温の上昇による台風の強大化が, 上 空のより大きな昇温によってある程度抑制されることを 意味する。すなわち, 将来の台風強度を左右する支配的 要因は, 海面水温の上昇量と, それに相対的な上空気温 の昇温量である。後述するように, 後者はAOGCMによ る予測で少なからずばらつきがあり, 大きな不確実要因 となる。

\section{2 Holland $の$ MPI}

以下では, Holland の MPI 理論のみを扱う。

Holland の MPI で基本となるのは, 海面の気圧深度を上 空の暖気核構造と関係づける静力学平衡の式

$$
\delta p_{c}=\frac{p_{s}}{T_{v}\left(p_{s}\right)} \int_{p_{s}}^{p_{t}} \delta T_{v} d \ln (p)
$$

である。ここで, $\delta p_{c}$ は気圧深度, $p$ は気圧（鉛直方向の 
独立変数), $p_{s}$ は地表気圧, $p_{t}$ は台風の上端における気圧, $T_{v}$ は仮温度, $\delta T_{v}$ はその偏差（台風の周辺環境との差）で ある。仮温度とは, 水蒸気を含む空気の状態方程式を簡 便に扱うために導入される仮想的な温度であり, 気温 $T$ と 水蒸気混合比 $r_{v}$ を用いて, 近似的に $T\left(1+0.61 r_{v}\right)$ と表さ れる。

$\delta T_{v}$ は, 与えられた熱環境に対して, 暖気核の形成過程 を計算することで決定される。この計算では, 上昇気塊 の初期の相対湿度と, 台風の眼の相対湿度の值が主な調 整パラメータである。現状気候における熱環境の条件と して, JRA-25 と呼ばれる全球大気の長期再解析データ ${ }^{14)}$ の月別気候值（1979-2004 年平均）を用い, MPI の計算 值が観測された中心気圧の下限值と整合するようにパラ メータを調整すると, 図 3 に示す MPI 気候值の年変化が 得られる。この図では, 日本近海を含む緯度帯別に, MPI に対応寸る中心気圧の気候值と実際の台風の最低中心気 圧を比較している。実際の台風は必ずしもMPI の強度ま で発達するわけではないが，最低中心気圧の下限值が MPI で概ね包絡されることを確認できる。

実際の台風の中には，特に 9 月以降の台風シーズンの 後半で, MPI に対応する中心気圧を下回るものも見られ る。この点については, MPI 自体の精度の問題の他に, 空間分解能の問題がある。例えば，台風が発達しながら 北上する場合に，図に示した最大強度に達した場所での MPI は, より南方の高水温域での発達が反映されず過小 評価となる。逆に，6-7 月の台風シーズンの早い時期で は, 低緯度の MPI 気候值で示されるような強い台風がほ とんじ観測されていない。この点については，この時期 の台風の発達が, MPI で考慮されない力学的な条件に制 約されることが示唆される。

なお，実際の台風の最低中心気圧には，観測方法の変 遷によるバイアスが含まれることに注意が必要である ${ }^{15}$ 。 特に, 西部北太平洋では現業的な航空機観測が 1987 年に 中止された影響が大きく, $900 \mathrm{hPa}$ を下回る台風の頻度が その前後で大きく異なる。

\section{3 中心気圧と風速の関係}

台風域内の風速は軸対称の傾度風で近似される。傾度 風の前提となる気圧傾度力, コリオリ力, および遠心力 の釣り合いは, 円筒座標系 $(r, \theta)$ を用いて,

$$
\frac{v_{\theta}^{2}}{r}+f v_{\theta}=\frac{1}{\rho} \frac{\partial p}{\partial r}
$$

と表される。ここで， $v_{\theta}$ は反時計回りを正とする接線風 速, $f$ はコリオリ係数, $\rho$ は空気の密度である。この式は, 静力学平衡を考慮して, 絶対角運動量の鉛直勾配と気温
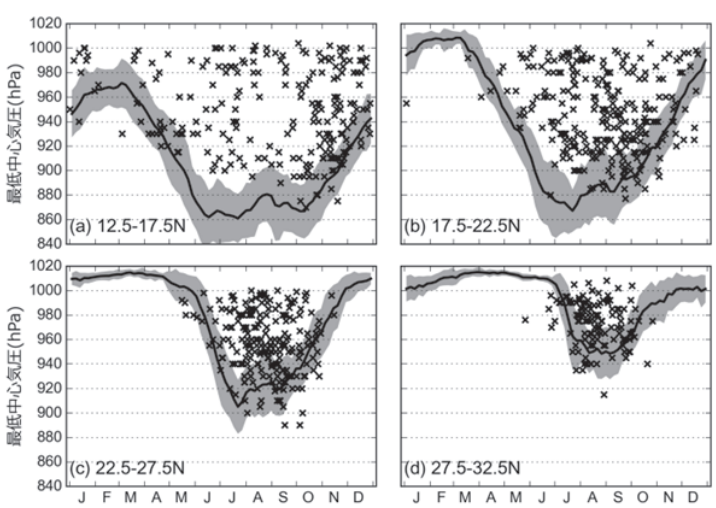

図 3 西部北太平洋の緯度帯別 MPI 気候值の年サイクル と観測された台風の最低中心気圧の比較

文献 ${ }^{5}$ Fig. A 1 に基づく。陰影部は年々変動の標準偏差の幅 $( \pm 1$ 倍)。観測は気象庁の 1951-2010 年のベストトラックデータ。

の水平公配との関係

$$
\frac{1}{r^{3}} \frac{\partial M_{\theta}^{2}}{\partial z^{*}}=\frac{R}{H} \frac{\partial T}{\partial r}
$$

に変形される ${ }^{16)}$ 。ここで, $M_{\theta}$ は $v_{\theta} r+f r^{2} / 2$ で定義され る絶対角運動量, $z^{*}$ は対数気圧系での鉛直座標, $R$ は乾燥 空気の気体定数, $H$ は $R \bar{T} / g$ で定義されるスケールハイト ( $\bar{T}$ は地球の平均気温, $g$ は重力加速度) である。 $z^{*}$ は $-H \log \left(p / p_{s}\right)$ で定義される。

Holland の MPI 理論では, 式(1)で表されるように, 気 温偏差を気圧の対数で積分した量が気圧深度の目安とな る。したがって, 式(3)によって, 風速の変化率が気圧深 度の变化率から見積られる。具体的には, 暖気核構造の 風速場 (大気境界層の上端で最大, 上空に向かって減少) を考慮して $\partial M_{\theta} / \partial z^{*} \sim v_{\theta} r / H$ を仮定し, 式(3)をrについて 積分して, 暖気核構造の気温偏差 $\delta T$ を

$$
\delta T \sim \frac{U L}{R}\left(f+\frac{2 U}{L}\right)
$$

のように近似する。ここで，Uは接線風速のスケール（最 大風速と見な寸) , $L$ は暖気核構造の水平スケールである。 温暖化しても台風の水平スケールは変わらない (Lは一定) と仮定して, 上式の対数微分をとり, $\delta T$ と $\delta p_{c}$ の近似的 な比例関係を考慮すると

$$
\frac{\Delta\left(\delta p_{c}\right)}{\delta p_{c}}=\left[1+\frac{1}{1+f L /(2 U)}\right] \frac{\Delta U}{U}
$$

を得る。左辺[]中に含まれるU/(fL)はロスビー数と呼ば れる無次元量（コリオリ力に対する慣性力の比）で，台 風の場合は 1 より大きい值をとる。したがって, []内は 2 より若干小さい值であり, 風速の変化率は $\delta p_{c}$ の変化率の 0.5 倍より若干大きい值となる。

この倍率は, 台風の最大地表風速 $v_{s}$ と中心気圧の関係 を表す経験式 ${ }^{17}$ 


$$
v_{s}=a\left(\delta p_{c}\right)^{b}
$$

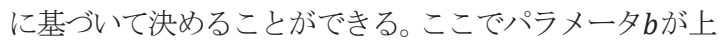
記の倍率に相当する。気象庁の現業解析で使われている 西部北太平洋の最大風速 $(10 \mathrm{~m}$ 高度の 10 分平均風速) と 中心気圧のデータ ${ }^{18)}$ を上式で近似すると， $b$ の值は 0.53 となる。

台風域内の海面気圧分布が与えられると, 傾度風平衡 の関係によって, 台風の中心から周辺環境までの風速分 布がパラメータ化される。気圧分布には次の経験式 ${ }^{19)}$

$$
p_{s}=p_{c}+\delta p_{c} \exp \left(-\frac{r_{m}}{r}\right)
$$

がしばしば使われる。ここで $r_{m}$ は最大旋衡風速半径であ る。この経験式を用いると, 流線と流跡線の曲率半径 $\left(R_{S}\right.$, $\left.R_{t}\right)$ の関係

$$
R_{s}=R_{t}\left(1-\frac{V_{c} \cos \gamma}{v_{\theta}}\right)
$$

を考慮して, 移動する台風に伴う傾度風の風速を求める 式として

$$
v_{\theta}=\frac{f r-V_{c} \cos \gamma}{2}\left[-1+\sqrt{1+\frac{4 r G}{\left(f r-V_{c} \cos \gamma\right)^{2}}}\right]
$$

を得る。ここで， $V_{c}$ は台風が移動するスピード， $\gamma$ は流線

（気圧分布の等值線に相当）と台風の移動方向の成寸角, Gは次式で表される気圧傾度力である。

$$
G=\frac{1}{\rho} \delta p_{c} \frac{r_{m}}{r^{2}} \exp \left(-\frac{r_{m}}{r}\right)
$$

この導出で, 式(2)の左辺第 1 項（遠心力）のrはR 換えられている。

この風速分布は, 従来から, 構造物の設計風速を決め る手順などで利用されている ${ }^{20,210}$ 。例として, $p_{c}$ が $930 \mathrm{hPa}$, $r_{m}$ が $60 \mathrm{~km}, V_{c}$ が $30 \mathrm{~km} / \mathrm{h}$ で北東に進む場合の分布を図 4 に示す。台風の移動に伴う非軸対象の風速成分は, 台風 の中心付近で相対的に大きく, 経験的に知られるように, 最大風速は台風の進行方向に対して右側に現れる。この 風速分布は少数のパラメータで規定でき扱い易いが，実 際の風速分布との違いもいくつか指摘されている ${ }^{22) 。 ま ~}$ た，日本に接近・上陸するような中緯度に移動してくる 台風は, 多かれ少なかれ温帯低気圧の構造に遷移する過 程にあり，同心円状の構造が失われる。

このような実際の台風との違いはあるものの，パラメ 一タ化された風速分布は, 温暖化に伴う背景的な変化を 定量化して, 傾向を把握するには有用である。図4には, $\delta p_{c}$ の変化率が $6.5 \%$ の場合（3. 2 参照）に対寸る風速 の変化率も示している。風速の変化率は, 最大風速半径 に近い中心付近は $3.5 \%$ 程度で, 周辺に向かって大きくな る。 $\delta p_{c}$ の変化率に対寸る比率として先に求めた 0.53 は,

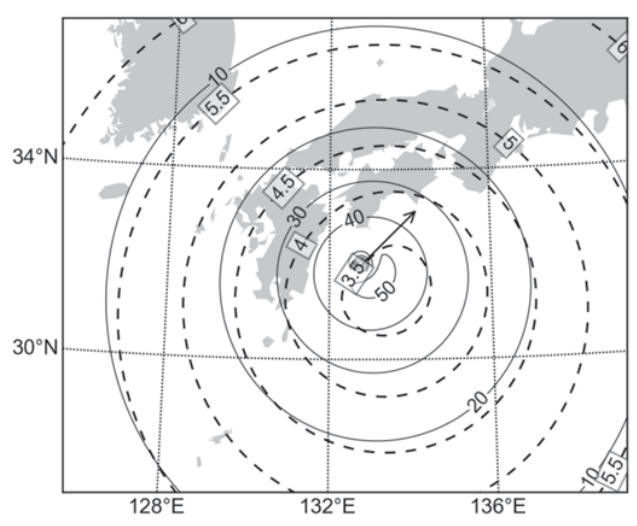

図 4 台風域内の地上風分布の例

実線コンターは風速 (単位 $\mathrm{m} / \mathrm{s}$ )、破線コンターは気圧深度の変 化率が $6.5 \%$ (全球平均で $1^{\circ} \mathrm{C}$ 昇温に相当) の場合の風速の変 化率 (単位\%)。

最大風速の変化率をスケーリングする值としては妥当で あるが，中心から離れた領域の風速の場合は多少割増と なり，0.6-0.8 程度が適当である。

\section{3. 地球温暖化による MPI の変化}

3. 1 対象海域とパターンスケーリング

以下では, 日本の本土に上陸する最強クラスの台風を 想定して, 緯度 30N に沿った領域の 8-9 月平均の熱環境 を対象に，地球温暖化に伴う MPI の変化を評価する。現 状気候に JRA-25 の気候值を用いると, 現状の熱環境に対 する MPI は $944 \mathrm{hPa}$ (周辺気圧 $1009 \mathrm{hPa}$ に対し， $\delta p_{c}$ は $65 \mathrm{hPa})$ と計算される。この值は, 最強クラスの台風の上 陸時の中心気圧として妥当であるが，入力データに用い る気候值や，MPI 計算のパラメータ設定に依存する。そ こで, 地球温暖化による変化は, MPI の值ではなく, $\delta p_{c}$ の 変化率で評価する。この変化率は, 基準とする現状気候 の值にほとんど依存しないことを確認しており，汎用性 がある。例えば, 伊勢湾台風（1959 年）や室戸台風（1934 年）の事例（ $\delta p_{c}$ は 80-100 hPa 程度）を基準にとると, より低頻度の極值の変化を評価できる。 $\delta p_{c}$ の変化率は, 前項で述べたように風速の変化率に換算でき, 構造物等 の設計外力に地球温暖化による変化を考慮するための基 礎情報となる。なお，本稿では扱わないが，降水強度を 評価する理論スキーム ${ }^{23}$ を導入して, 台風に伴う強雨に ついも地球温暖化による変化を評価できる7”。

地球温暖化による熱環境の変化は, シナリオや気候感 度の不確実性を扱うために，パターンスケーリング ${ }^{24)}$ 考え方に基づいて評価する。パターンスケーリングは, 多数の AOGCM による気候予測の結果から，基本となる 
偏差分布（パターン）をあらかじめ用意しておき，別途 評価される全球で平均した年平均地表温度偏差 $\left(\Delta \overline{T_{S}}\right)$ で その分布をスケーリングする手法である。ここでは，偏 差を現状気候との差とし，現状気候に偏差を加えたもの を将来の值とする。 $\Delta \overline{T_{S}}$ は個々の AOGCM やその平均の 特性を模擬するよう調整された簡易気候モデルで計算す る。将来の気温や降水量などの偏差の空間分布は, 予測 に使われる AOGCMによって異なるが，同一モデルの結 果や多数モデルを平均した結果は, 将来のシナリオや時 点によらず類似することが知られている。パターンスケ ーリングでは，この類似性を根拠として，任意のシナリ オの任意の時点について, 多数の AOGCM の平均やばら つきを考慮した偏差場を得る。

本研究では, 図 5 に示寸地表温度 (海面と陸面の温度) と対象海域における上空気温の偏差場を基本パターンと する。これは, 第 3 期結合モデル相互比較 (Coupled Model Intercomparison Project Phase 3: CMIP3) における A1B シナ リオの気候予測 ${ }^{25}$ から, 多数の AOGCM の結果を平均し て得たものである。地表温度の偏差場は, $\Delta \overline{T_{S}}$ を基淮とす る 8-9 月の偏差の比率を表しており, 対象海域 (29-31N, 127-139E）は 0.86 である。上空気温の偏差場は，当該海 域の海面水温偏差を基準とする比率を表している。これ によって，与えられた $\Delta \overline{T_{S}}$ に対し，その 0.86 倍が対象海 域の 8-9 月の海面水温偏差となり, その值を上空気温の
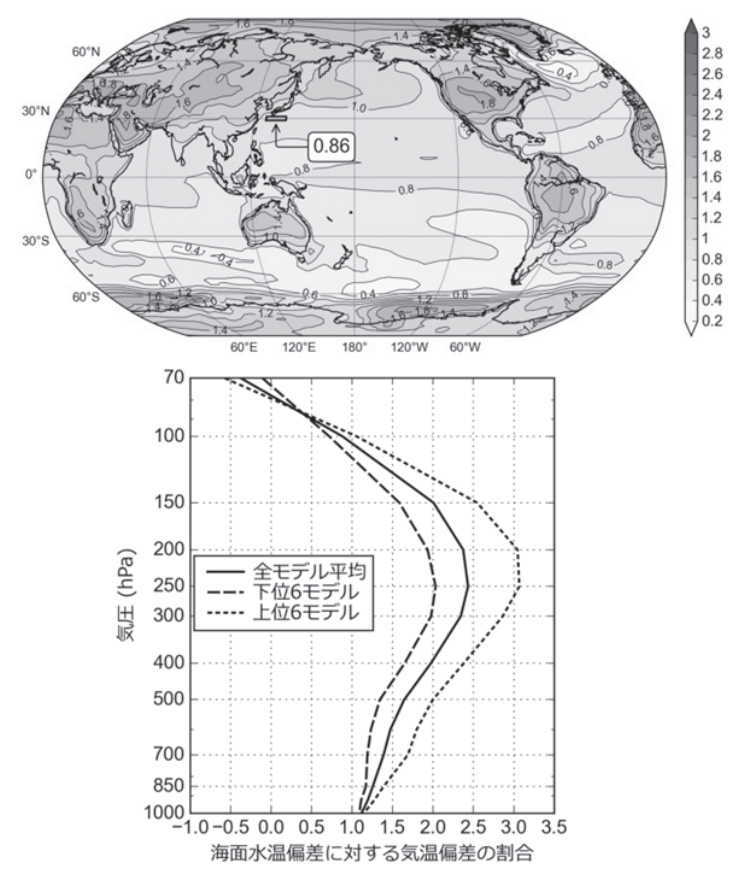

図 5 地表温度と対象域上空気温の基準偏差
基淮偏差にかけたものが気温偏差の分布となる。

上空の気温偏差は, MPI の計算における主要な不確実 要因となる。ここでは, CMIP3 の全モデルの平均を最良 推定值とし, $200 \mathrm{hPa}$ レベルの気温偏差の上位と下位の 6 モデルの平均を不確実範囲とする。この 6 モデルの平均 は CMIP3 モデル全体の四分位に相当する。 $\Delta \overline{T_{S}}$ の不確実 性は, 次項で述べるように, 複数のシナリオに対するア ンサンブル計算で扱う。必要に応じて, 対象海域の海面 水温を求める係数の不確実性も考慮できるが, 以下の事 例では 0.86 に固定している。

CMIP3 モデルは, 2007 年発表の IPCC 第 4 次評価報告

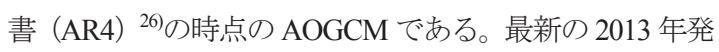
表の第 5 次評価報告書 (AR5) ${ }^{27)}$ では, CMIP3 の後継と なる $\mathrm{CMIP}^{28)}$ の AOGCMによる気候予測が基になってい る。CMIP5 モデルは CMIP3 モデルと比べて現状気候の再 現性が向上しているが，モデル平均の空間分布や気候感 度の幅は CMIP3 モデルと同様である。ただし, 図 5 に示 寸上空の気温偏差は局所的なものであり, CMIP3 と CMIP5 の違いについては今後確認寸る必要がある。

3. 2 結果

パターンスケーリングによって, 任意の場所と時点に おける $\delta p_{c}$ の変化率が $\Delta \overline{T_{S}}$ の関数となる。対象海域の場合 は図 6 に示寸結果となる。 $\delta p_{c}$ は $\Delta \overline{T_{S}}$ が大きくなるにつれ てやや非線形的に増加寸る。ただし, 上空の気温偏差に 関係する不確実性は非常に大きく, 温暖化で強度が若干 弱まることを示すマイナスの值から, 最良推定值の 2 倍 程度の範囲におよぶ。不確実性の幅が小さい方に広くな っているのは, 図 5 に示した上空の気温偏差の幅が高温 側に広くなっていることに対応寸る。図 6 には，代表的 な值として, $\Delta \overline{T_{S}}$ が $1^{\circ} \mathrm{C}$ と $2^{\circ} \mathrm{C}$ 場合を明示している。最 良推定值はそれぞれ $6.5 \%$ と $14.2 \%$ で，この結果は既往の

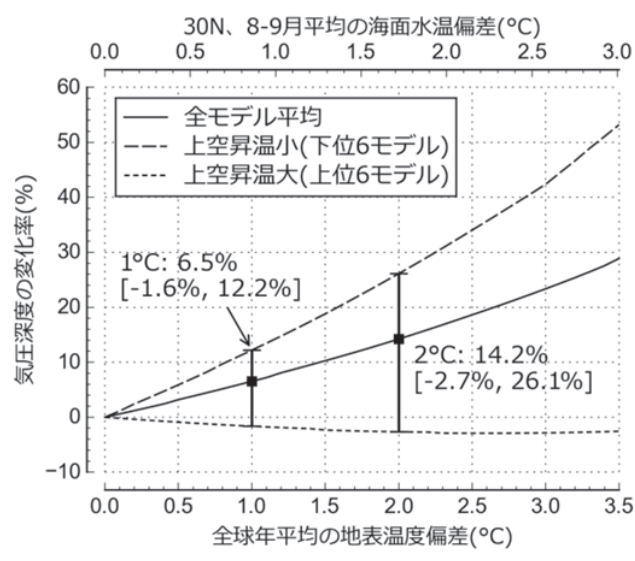

図 6 気圧深度の变化率と地表温度偏差の関係 
観測情報や数值計算に基づく研究 ${ }^{29,30)}$ と概ね 整合寸る。6.5\%の変化は, 現状気候の $\delta p_{c}$ が $65 \mathrm{hPa}$ の場合, 中心気圧が $944 \mathrm{hPa}$ から 940 $\mathrm{hPa}$ （不確実範囲は 945-936 hPa）に変化する ことに対応する。

図 6 の結果は様々なシナリオの将来予測に 応用できる。一例として, CMIP5 の気候予測 に使われた代表濃度経路（Representative Concentration Pathway: RCP) ${ }^{31}$ に対する確率論 的評価を図 7 に示す。 $\mathrm{RCP}$ は大気 $\mathrm{CO}_{2}$ 濃度な どによる放射強制力が異なる 4 本の経路で構 成される。各経路は RCP を冠した数值でラべ ルづけされており,その数值は2100 年頃の放 射強制力（単位：W/m²）を表す。放射強制力 の範囲は, 既往のシナリオの大半をカバーす るように決められており, RCP8.5 と RCP2.6 がそれぞれ上限と下限に相当する。

\section{ここでは, CMIP5 の多数の AOGCM で計}

算される $\Delta \overline{T_{S}}$ のばらつきに注目し, $\delta p_{c}$ は最良推定值のみ を扱っている。 $\Delta \overline{T_{S}}$ は, CMIP5 モデルの特性を模擬する 簡易気候モデルで計算している。この簡易気候モデルは, 大気 $\mathrm{CO}_{2}$ 濃度などの変化に対する $\Delta \overline{T_{S}}$ の応答をインパル 不答関数で定式化したものである ${ }^{32}$ 。温度応答は 7 個 のパラメータで規定され, CMIP5 の個別の AOGCM を模 擬する設定と，そのばらつきを表すパラメータの統計モ デルが用意されている。ここでは, CMIP5 モデル平均の パラメータと統計モデルで得られる 10,000 サンプルのパ ラメータを用いて, 各 RCP に対する簡易気候モデルの計 算を行い, $\Delta \overline{T_{S}}$ の代表值と確率分布を求めた。

CMIP3 やCMIP5 の多数の AOGCM による気候計算は, 世界のモデル開発機関が自主的に CMIP に参加して実施 したもので，その中に含まれる AOGCM は系統的に選択 されたものではない。この種の多数モデルは「ensemble of opportunity」と呼ばれており, 必ずしも気候感度などの不 確実範囲が適切とは限らないといった問題が認識されて いる ${ }^{33}$ 。本研究では, 温度応答の特性を把握できる 26 個 のAOGCM を参照しており, 平衡気候感度 (大気 $\mathrm{CO}_{2}$ 濃 度が 2 倍になって平衡する時の $\Delta \overline{T_{S}}$ ) と過渡気候応答（濃 度が年率 $1 \%$ で増加して 2 倍に達する 70 年目の $\Delta \overline{T_{S}}$ ) の確 率密度は図 7(c)に示寸分布となる。平均と $90 \%$ 幅は, 平 衡気候感度が $3.1^{\circ} \mathrm{C}\left[2.0-4.6^{\circ} \mathrm{C}\right]$, 過渡気候応答が $1.8^{\circ} \mathrm{C}$ $\left[1.2-2.4^{\circ} \mathrm{C}\right]$ である。過渡気候応答はほぼ対称の分布形であ るが, 平衡気候感度は高温側の裙がより広がる形となる。 各 RCP に対する $\Delta \overline{T_{S}}$ の代表值 (CMIP5 モデル平均相当)
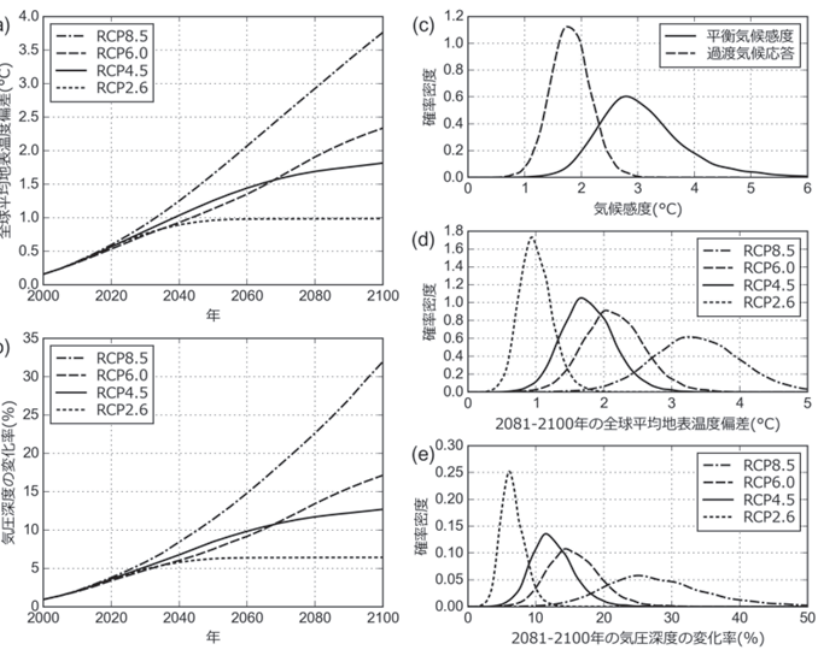

図 7 RCP シナリオに対する地表温度偏差と気圧深度変化率の評価 代表值の時系列（(a)-(b)，CMIP5 モデル平均相当）と確率密度 ((c)-(e)) : (a) 全球平均温度偏差（1980-1999 年基準)，(b) 気圧深度変化率，(c) 気候感度, (d) 2081-2100 年の全球平均温度偏差, (e) 2081-2100 年の気圧深度変化率。

は，図 7(a)に示寸時間変化となる。ここで，偏差の基準 は 20 世紀末の 20 年平均としている。 $\Delta \overline{T_{S}}$ は 2040 年頃に $1{ }^{\circ} \mathrm{C}$ 程度で, その後シナリオの違いが徐々に拡大し, 21 世紀末には $1^{\circ} \mathrm{C}$ から $3.8^{\circ} \mathrm{C}$ 範囲となる。 $\delta p_{c}$ の変化率も 基本的に同様の変化傾向となる。2 1 世紀後半のシナリ才 間の違いは, 図 6 に示した上空気温偏差の不確実範囲と 同程度になる。AOGCM の温度応答の不確実性は, 各 RCP の任意時点で $\Delta \overline{T_{S}}$ の多数サンプルの結果から評価される。 21 世紀末の 20 年平均では, 図 7(d) と(e)に示す $\Delta \overline{T_{S}}$ と $\delta p_{c}$ の 確率密度が得られる。 RCP8.5 と RCP2.6 の密度分布はほ とんど重ならないが, その間に位置する RCP6.0 と RCP 4.5 は互いに重なる部分が大きく, RCP 8.5 と RCP2.6 のいず れとも部分的に重なる。密度分布の形状は, 平衡気候感 度より過渡気候応答の分布に近い。

以上のように，簡易気候モデルとパターンスケーリン グを援用した MPI の手法により，多数のシナリオと多数 の AOGCM の気温応答特性にわたる包括的な評価が得ら れる。この結果は, 詳細なダウンスケーリング等で, 特 定のシナリオと AOGCM を前提とする場合に，結果を定 量的に解釈寸る際にも有用となる。

\section{4. 結論}

本稿では，MPI の有用性と適用事例を紹介した。MPI の定式化は，現実の台風の発達の仕組みを単純化したも のであるが，過去の最強クラスの台風強度の年変化は， 現在気候に対寸るMPI と良く対応する。将来の台風強度 は, 海面水温の他に，上空の気温偏差の相対的な大きさ 
にも左右される。MPI による評価では，その両者が明示 的に考慮され, 地球規模の熱環境の変化に伴う台風強度 の変化が定量化される。MPI は, 地球温暖化による台風 の強大化を説明・定量化する理論としてだけでなく, 地 球温暖化に対する適応策を具体的に検討寸るための有用 な手法でもある。将来の台風強度の変化には, 大気 $\mathrm{CO}_{2}$ 濃度等のシナリオ, 気候感度等の地球の温度応答の特性, 上空の気温偏差をはじめとする気温上昇の空間分布とい った, 様々な不確実要因がある。MPI の手法は, 簡易気 候モデルとパターンスケーリングを援用して, 主要な不 確実要因を包括的に扱う確率論的評価に応用できる。そ の結果は, 構造物の設計外力等を評価する既存のスキー ムに適用できる。MPI の手法は, 台風強度の評価におい て, 複雑な気候モデルによるダウンスケーリングの手法 と相補的な関係にある。MPI の定式化は, 複雑な気候モ デルから得られる知見を基に改良されるべきものであり， ダウンスケーリングの結果は, MPI の評価結果と比較す ることで定量的な解釈と不確実情報が補完される。

謝辞

3. 2 の内容の一部は, 文部科学省「気候変動リスク 情報創生プログラム」(2012-16 年度) の領域テーマB「安 定化目標值設定に向けた社会経済シナリオに関する検 討・情報収集」の成果に基づく。

\section{参考文献}

1) Emanuel, K. A., "An air-sea interaction theory for tropical cyclones. Part I: Steady-state maintenance", Journal of the Atmospheric Sciences, Vol. 43, No. 6, pp. 585-605, (1986)

2) Emanuel, K. A., "Sensitivity of tropical cyclones to surface exchange coefficients and a revised steady-state model incorporating eye dynamics", Journal of the Atmospheric Sciences, Vol. 52, No. 22, pp. 3969-3976, (1995)

3) Holland, G. J., "The maximum potential intensity of tropical cyclones", Journal of the Atmospheric Sciences, Vol. 54, No. 21, pp. 2519-2541, (1997)

4) 筆保 弘徳, 宮本 佳明, 「発達過程と成熟期」, 台風研 究の最前線 (上) - 台風力学 -, 筆保 弘徳, 中澤哲夫 編, 気象研究ノート, 日本気象学会, pp. 65-91, (2013)

5) Tsutsui, J., "Changes in potential intensity of tropical cyclones approaching Japan due to anthropogenic warming in sea surface and upper-air temperatures", Journal of the Meteorological Society of Japan, Vol. 88, No. 3, pp. 263284, (2010)
6) Knutson, T. R., et al., "Tropical cyclones and climate change", Nature Geoscience, Vol. 3, No. 3, pp. 157-163, (2010)

7) 筒井 純一,「温暖化による台風強度の変化とその影響 一の適応」, 土木学会論文集 G (環境)，Vol. 67,pp. I17I26, (2011)

8) Camp, J. P. and Montgomery, M. T., "Hurricane maximum intensity: Past and present”, Monthly Weather Review, Vol. 129, No. 7, pp. 1704-1717, (2001)

9) Smith, R. K., Montgomery, M. T., and Vogl, S., “A critique of Emanuel's hurricane model and potential intensity theory", Quarterly Journal of the Royal Meteorological Society, Vol. 134, pp. 551-561, (2008)

10) Emanuel, K. A., "The dependence of hurricane intensity on climate”, Nature, Vol. 326, pp. 483-485, (1987)

11) Henderson-Sellers, A., et al., "Tropical cyclones and global climate change: A post-IPCC assessment", Bulletin of the American Meteorological Society, Vol. 79, No. 1, pp. 19-38, (1998)

12) Knutson, T. R., Tuleya, R. E., and Kurihara, Y., "Simulated increase of hurricane intensities in a $\mathrm{CO}_{2}$-warmed climate", Science, Vol. 279, pp. 1018-1021, (1998)

13) Vecchi, G. A. and Soden, B. J., "Effect of remote sea surface temperature change on tropical cyclone potential intensity", Nature, Vol. 450, pp. 1066-1070, (2007)

14) Onogi, K., et al., "The JRA-25 reanalysis", Journal of the Meteorological Society of Japan. Ser. II, Vol. 85, No. 3, pp. 369-432, (2007)

15) Kossin, J. P., Knapp, K. R., Vimont, D. J., Murnane, R. J., and Harper, B. A., "A globally consistent reanalysis of hurricane variability and trends", Geophysical Research Letters, Vol. 34, No. 4, L04815, (2007)

16) Holton, J. R., "An introduction to dynamic meteorology", Third ed, Academic Press, 511p, (1992)

17) Atkinson, G. D. and Holliday, C. R., "Tropical cyclone minimum sea level pressure/maximum sustained wind relationship for the western North Pacific", Monthly Weather Review, Vol. 105, No. 4, pp. 421-427, (1977)

18）木場 博之, 萩原 武士, 小佐野 慎悟, 明石 修平, 「台 風の CI 数と中心気圧及び最大風速の関係」, 気象庁研 究時報, Vol. 42, pp. 59-67, (1990)

19) Schloemer, R. W., "Analysis and synthesis of hurricane wind patterns over Lake Okechobee, Florida", U. S. Government Printing Office Hydrometeorological Report 31, C30.70:31, (1954) 
20) 藤井 健, 光田 寧, 「台風の確率モデルの作成とそれ による強風のシミュレイション」, 京都大学防災研究 所年報 29, B-1,(1986)

21）山崎 智之, 石川 智巳, 大熊 武司, 田村 幸雄, 北嶋 知樹, 中村 秀治, 加藤 央之, 「送電用鉄塔の而風設計 のための風向別基本風速に関寸る検討」, 日本風工学 会論文集, Vol. 29, No. 3, pp. 19-34, (2004)

22) Kepert, J. D., "Tropical cyclone structure and dynamics", in Global perspectives on tropical cyclones from science to mitigation, Chan, J.C.L. and J.D. Kepert (eds), World Scientific Series on Asia-Pacific Weather and Climate, 4, World Scientific: Singapore, pp. 3-53, (2010)

23) O'Gorman, P. A. and Schneider, T., "The physical basis for increases in precipitation extremes in simulations of 21st-century climate change", Proceedings of the National Academy of Sciences of the United States of America, Vol. 106, No. 35, pp. 14773-14777, (2009)

24) Mitchell, T., "Pattern scaling: An examination of the accuracy of the technique for describing future climates", Climatic Change, Vol. 60, No. 3, pp. 217-242, (2003)

25) Meehl, G. A., et al., "The WCRP CMIP3 multimodel dataset: A new era in climate change research", Bulletin of the American Meteorological Society, Vol. 88, No. 9, pp. 1383-1394, (2007)

26) IPCC, "Climate Change 2007: The physical science basis. Contribution of Working Group I to the Fourth Assessment Report of the Intergovernmental Panel on Climate Change", Solomon, S., et al. (eds), Cambridge University Press, 996p, (2007)
27) IPCC, "Climate Change 2013: The physical science basis. Contribution of Working Group I to the Fifth Assessment Report of the Intergovernmental Panel on Climate Change", Stocker, T.F., et al. (eds), Cambridge University Press, 1535p, (2013)

28) Taylor, K. E., Stouffer, R. J., and Meehl, G. A., “An overview of CMIP5 and the experiment design", Bulletin of the American Meteorological Society, Vol. 93, No. 4, pp. 485-498, (2012)

29) Oouchi, K., Yoshimura, J., Yoshimura, H., Mizuta, R., Kusunoki, S., and Noda, A., "Tropical cyclone climatology in a global-warming climate as simulated in a $20 \mathrm{~km}$-mesh global atmospheric model: Frequency and wind intensity analyses", Journal of the Meteorological Society of Japan. Ser. II, Vol. 84, No. 2, pp. 259-276, (2006)

30) Elsner, J. B., Kossin, J. P., and Jagger, T. H., "The increasing intensity of the strongest tropical cyclones", Nature, Vol. 455, pp. 92-95, (2008)

31) Moss, R. H., et al., "The next generation of scenarios for climate change research and assessment", Nature, Vol. 463, pp. 747-756, (2010)

32）文部科学省研究開発局，「安定化目標值設定に資する 気候変動予測及び気候変動研究の推進・連携体制の構 築」, 気候変動リスク情報創生プログラム 平成 26 年 度研究成果報告書, (2015)

33) Tebaldi, C. and Knutti, R., "The use of the multi-model ensemble in probabilistic climate projections", Vol. 365, pp. 2053-2075, (2007) 